УдК 351

C. 3. Моменський,

д.е. н., професор, Житомирський державний технологічний університет,

B. В. Нонік,

к. ю. н., проректор з науково-педагогічної роботи, юридичних

та сочіальних питань, Житомирський державний технологічний університет

I. Г. Сергієнко,

магістр, Житомирський державний технологічний університет

DOI: $10.32702 / 2306-6814.2019 .6 .116$

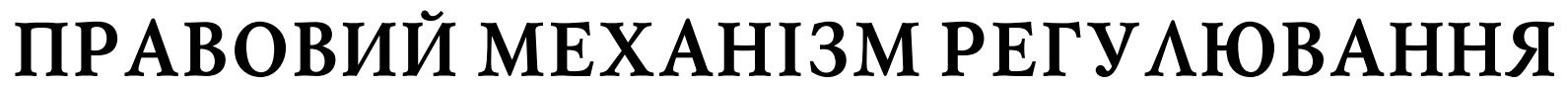 ПРОФЕСІЙНОЇ ЕТИКИ В СИСТЕМІ АЕРЖАВНОГО УПРАВ АІННЯ
}

\author{
S. Moshenskyi, \\ Doctor of economics, profesor, Zhytomyr State Technological University \\ V. Nonik, \\ $\mathrm{PhD}$ in Law, Vice-Rector scientific pedagogical work, legal and social nutrition, \\ Zhytomyr State Technological University \\ I. Serhiienko, \\ Master's Degree, Zhytomyr State Technological University
}

\section{LEGAL MECHANISM FOR REGULATION OF PROFESSIONAL ETHICS IN THE SYSTEM OF PUBLIC ADMINISTRATION}

Устатті досліджено міжнародний досвід нормативно-правового забезпечення функціонування інститутуетики державних службовців, принципи етики поведінки посадових осіб і службовців держапарату закордонних країн, а також проаналізовано механізми контролю за дотриманням професійної етичної поведінки державних службовців закордоном. Доведено, що одним з найважливіших факторів у професійномустановленні державного службовця, як показує міжнародний досвід, є вивчення етичних принципів роботи та моральне виховання. У практиці багатьох країн широко розповсюджений досвід впровадження предмета етики, а такожетикетуділових відносин упрограми підготовки, перепідготовки та підвищення кваліфікації державних службовців різного рангу.

The proclaimed course of Ukraine to the European system of values obliges to introduce qualitatively new standards of public administration based on the experience of the least-squalid countries.

The experience of the United States shows that the viability and legitimacy of the political system largely depend on the extent to which state institutions and senior officials meet the prevailing values and ideals in society, and how much their behavior meets the standards of social morality.

After analyzing the content of the ethical principles of the subjects of state administration, it was found that the main requirement for US civil servants is the proper performance of their duties, honesty and responsibility before the state and society. In EU Member States, ethics and ethics for civil servants are given particular attention; public administration has to meet a number of ethical requirements, which include: cooperation with civil society, participation in planning and managing change, adaptability, mutual trust and open communication, etc.

The practice of consolidation in legal acts of moral requirements to officials is dictated, above all by the need to support them with the help of efficient mechanisms. Disciplinary, administrative and even criminal liability for violating the requirements for the official conduct of officials, management bodies and employees is widespread and confirmed by the laws of a number of countries.

In many countries, effective monitoring mechanisms for maintaining the necessary level of ethics 
in the conduct of civil servants have become specialized bodies that monitor and assess moral acts: commissions and ethics committees, administrative and corporate courts, and so on.

It is proved that one of the most important factors in the professional development of a civil servant, as the international experience shows, is the study of ethical principles of work and moral upbringing. In practice, many countries have widespread experience in introducing ethics, as well as etiquette of business relations into training, retraining and qualification programs for civil servants of different rank.

Ключові слова: держаВна служба, державний службовеиь, професійна етика, складові профресійної етики, інститут етики держаВних службовиі८, контроль за дотриманням профессійної етики.

Key words: public service, civil servant, professional ethics, components of professional ethics, institute of ethics of civil servants, control over observance of professional ethics.

\section{ПОСТАНОВКА ПРОБАЕМИ}

Проголошений Україною курс до європейської системи цінностей зобов'язує запровадити якісно нові стандарти державного управління, спираючись на досвід розвинених країн.

Особливо цінним $€$ досвід тих країн, яким вдалося потрапити до двадцятки найменш корумпованих країн і домогтися певних успіхів в управлінні сорерою моральних відносин у державній службі своїх країн [9].

Питання регулювання професійної етики в системі державного управління розглядали у своїх працях Загороднюк С., Карковська Р., Ковбасюк Ю., Крайнік П., Лагодієнко О., Рудакевич М.

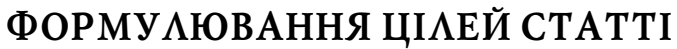

Метою статті $€$ дослідження іноземних особливостей щодо функціонування інституту етики державних службовців з метою удосконалення профресійної етики державних службовців в Україні.

\section{ВИК АААЕННЯ ОСНОВНОГО МАТЕРІААУ}

У США, Великобританії, ФРН і багатьох інших країнах західної демократії доступ до державної служби відкритий і вільний для кожного громадянина. Службовці приймаються на роботу в апарат за конкурсом без будь-якої соціально-політичної дискримінації, але ось принцип моральності "працює" досить суворо. Службовці не мають права брати участь у формуванні партійних структур і партійних фрондів, виступати з партійнополітичними заявами, займати партійні пости або діяти в інтересах тієї чи іншої конкретної партії, робити вчинки, що провокують конфрлікт інтересів, тобто робити все те, що суперечить політично неупередженому виконанню службових обов'язків. Будь-яка дія або висловлювання, що не узгоджується з інтересами держави, розглядається як прояв нелояльності і як акт, несумісний 3 перебуванням на державній службі.

Будівництво морального фундаменту цивільної служби в багатьох країнах починалося зі створення етичного кодексу як нормативного документа, що містить систему етичних принципів, норм і правил, якими повинні керуватися державні службовці у своїй професійній діяльності. Це був перший, але необхідний етап у тривалому процесі формування корпусу державної служби як інституту суспільного служіння [9].
Піонером у цьому виступили США. Перший кодекс етики в цій країні був розроблений Міжнародною асоціацією адміністраторів міст (нині Міжнародна асоціація управління міст / округів) ще в 1924 році. Через тридцять з гаком років в 1958 році був прийнятий Кодекс етики урядової служби в фрормі резолюції Конгресу США, підкріплений в 1965 році законодавчим нормативним актом "Стандарти поведінки посадових осіб" [2].

За США пішли й інші країни: в 1985 році в Канаді був прийнятий Ціннісний етичний кодекс державних службовців, в 1995 році в Німеччині з'явився Кодекс антикорупційної поведінки, а також Рекомендації по його дотриманню, до яких додавалося "Керівництво до дії", призначене для керівників, оскільки ефективність заходів впливу та попередження корупції, на думку німецьких законодавців, у першу чергу залежить від вищих посадових осіб. Процес прийняття кодексів службової професійної етики значно активізувався у зв'язку зі зверненням Комітету міністрів Ради Європи до урядів країн-учасниць ЄС розробити національні кодекси поведінки державних службовців, керуючись затвердженими ними 2000 року Рекомендаціями "Про кодексах поведінки державних службовців" [1].

Світовий досвід показує, що при певних історично сорормованих умовах, закріплення моральних цінностей цивільної служби в правових актах обумовлюється успіхом втілення їх в життя. Тут США знову опинилися на крок по переду інших, прийнявши в 1978 році в рамках ресрормування цивільної служби Закон про урядову етику 3 кінця 80-х років етичні вимоги в держслужбі стають об'єктом найсуворішого як соціального так і правового контролю навіть на законодавчому рівні. Було визнано, що життєздатність і легітимність політичної системи багато в чому залежать від того, наскільки державні інститути і посадові особи вищого рангу відповідають пануючим у суспільстві цінностям і ідеалам, і на скільки їх поведінка відповідає нормам суспільної моралі. Тому в листопаді 1989 року був прийнятий Закон про реформу етичних норм, який поширив положення Закону про етику на всі гілки влади - законодавчу, виконавчу і судову. Указом президента США були затверджені "Принципи етики поведінки посадових осіб і службовців держапарату" (рис. 1).

Проаналізувавши зміст основних положень "Принципів етики", можна зробити висновок, що основною ви- 


\begin{tabular}{|c|c|}
\hline \multirow{10}{*}{ 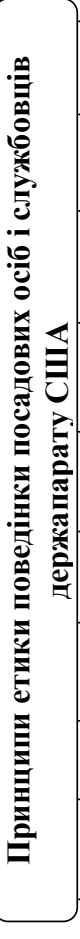 } & $\begin{array}{l}\text { державна служба є «службою суспільної довіри», що вимагає від службовця } \\
\text { ставити лояльність до Конституції, закону і етичних принципів вище від } \\
\text { особистих і приватних інтересів }\end{array}$ \\
\hline & перешкоджають добросовіснол \\
\hline & $\begin{array}{l}\text { він не повинен брати участь у фінансових операціях з викорис } \\
\text { службової інформації, яка не підлягає розголошенню, або доп } \\
\text { використання такої інформації для захисту чиїх-небудь прива }\end{array}$ \\
\hline & $\begin{array}{l}\text { le права вимагати або приймати будь-який } \\
\text { городи, що мають грошову вартість (крім } \\
\text { ом) }\end{array}$ \\
\hline & $\begin{array}{l}\text { він не повинен брати на себе несанкціоновані зобов’язання та давати } \\
\text { обіцянки, які передбачають покладання відповідальності за їх виконання на } \\
\text { урядову установу }\end{array}$ \\
\hline & 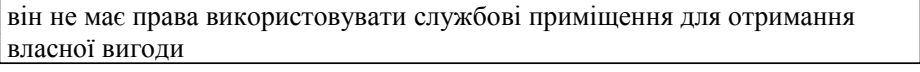 \\
\hline & $\begin{array}{l}\text { виконуючи службові обов'язки, він зобов'язаний діяти на непартійній } \\
\text { основі, без надання яких-небудь переваг тій чи іншій приватній організації } \\
\text { або особі }\end{array}$ \\
\hline & $\begin{array}{l}\text { він зобов’язаний інформ } \\
\text { факти розтрат, обману, }\end{array}$ \\
\hline & $\begin{array}{l}\text { він зобов'язаний суворо дотримуватися усіх законів і правил, спрямованих } \\
\text { на забезпечення рівних прав усіх громадян США }\end{array}$ \\
\hline & $\begin{array}{l}\text { він повинен добросовісно виконувати обов’язки, покладені на нього } \\
\text { законом як на громадянина країни, насамперед такі, як виплата федеральних } \\
\text { і місцевих податків }\end{array}$ \\
\hline
\end{tabular}

\section{Рис. 1. Принципи етики поведінки посадових осіб і службовців держапарату США}

Джерело: складено на основі [6].

могою до державних службовців США є належне виконання службових обов'язків, чесність та відповідальність перед державою та суспільством. Однак у документі відсутні принципи, що стосуються професіоналізму державних службовців.

Одночасно з затвердженням "Принципів" були створені спеціальні відомства, покликані здійснювати контроль за дотриманням етичних норм. У 1990 році був підписаний виконавчий наказ Президента США № 12731, який підтвердив раніше прийняті акти, за допомогою яких були введені в дію обов'язкові для всіх чиновників виконавчої влади США, включно з посадовими особами вищого рангу, загальні принципи етичної поведінки членів уряду і держслужбовців [9].

Сучасна етична система у Сполучених Штатах Америки охоплює суспільство і всі гілки державної влади, тобто в США рух за моральну владу і моральне суспільство - справа не лише державної влади, а й кожного громадянина. Варто зазначитити, що в стандартах етичної поведінки державного службовця США повноцінно реалізуються принципи свободи й справедливості, це принципова поведінка, спрямована на утвердження суспільних цінностей. "Етична поведінка державних службовців базується на комплексі правил, морально окресленій загальновизнаній реальності, яка постійно нагадує нам, хто ми $є$, ким ми були, ким ми станемо, ким можемо стати" [6].

Нормативно-правове кодування етичних вимог до державних службовців в подальшому отримало досить широке поширення у всіх провідних країнах світу. У Німеччині основні етичні цінності, проголошені для державних службовців, закріплені на конституційному рівні, а принципи співвідношення прав і відповідальності та ме- ханізми їх реалізації включені до федерального законодавства і Земельні закони про державну службу. В Ірландії в 1995 році прийнято Закон про етику в публічній сфрері. В Австралії в 1999 році Кодекс поведінки австралійських державних службовців був закріплений в ст. 13 Закону про державну службу. В Японії в 2000 році був прийнятий Закон про етику національної державної служби, а урядовим указом затверджені етичні правила державного службовця і норми адміністративних покарань за їх недотримання. В Угорщині Кодекс поведінки державних службовців в 2001 році включений до Закону XXIII про правовий статус цивільних службовців [8].

Основним підгрунтям етичного врядування в Європі $\epsilon$ досвід США.

У країнах-членах ЄС моральності і етичності державних службовців приділяється особлива увага, державне управління має відповідати ряду етичних вимог, до яких відносяться: співпраця з громадянським суспільством, участь в плануванні та управлінні змінами, здатність до адаптації, взаємна довіра і відкритість комунікацій тощо.

У травні 2000 року Комітет міністрів Ради Європи прийняв Страсбурзьку рекомендацію щодо регламентації поведінки державних службовців країн - членів Ради Європи (Етичний кодекс). Тобто національні кодекси поведінки державних службовців повинні бути розроблені відповідно до цієї Рекомендації. Етичний кодекс державного службовця розкриває суть і зміст основ профресійної етики державних службовців. Важливою особливістю даного документа $€$ формулювання його призначення і визначення кола осіб, на поведінку яких поширюються зазначені етичні норми. Визнання та дотримання Кодексу $є$ складовою частиною умов праці державного службовця. Включення його (Кодексу) положень в трудовий договір (контракт) приписує нормативний характер виконання [4].

Практика закріплення в правових актах моральних вимог до чиновників, продиктована, на наш погляд, перш за все необхідністю підтримати їх (моральноетичні вимоги) за допомогою дієвих механізмів. Дисциплінарна, адміністративна та навіть кримінальна відповідальність за порушення вимог до службового поводження посадових осіб, органів управління і службовців сьогодні широко поширена та підтверджена законами ряду країн.

"Британську державну службу дослідники характеризують як таку, що відрізняється високою корпоративною етикою і суворою відповідністю кодексу адміністративної моралі. Вважається, що високий рівень моралі державних службовців завжди був предметом особливої гордості британського суспільства. У світі відома британська "традиція" державної служби, що регламентується моральним кодексом і підзвітна парламентському комітету з бюджетного контролю. Поведінка "слуг корони" регламентується етичним Кодексом державно- 
Таблиця 1. Механізми контролю за дотриманням професійної етичної поведінки державних службовців за кордоном

\begin{tabular}{|c|c|c|}
\hline Назва країни & Органи контролю & Нормативно-правове регулювання \\
\hline Франція & $\begin{array}{l}\text { Центральний департамент по запобіганню корупції, } \\
\text { Міжміністерська комісія з розслідування контрактів, } \\
\text { що укладаються службовцями, і Вища рада з етики в } \\
\text { національній політиці, Генеральні інспекції при } \\
\text { міністерствах }\end{array}$ & $\begin{array}{l}\text { Державна програма «Генеральна } \\
\text { ревізія державної політики» }\end{array}$ \\
\hline Великобританія & $\begin{array}{l}\text { Комісія по державній службі, Комітет з питань } \\
\text { стандартів в публічній сфері }\end{array}$ & $\begin{array}{l}\text { Посадова інструкція для парламенту } \\
\text { «Постійні правила» }\end{array}$ \\
\hline Японія & Комісія з етики державних службовців & $\begin{array}{l}\text { Закону «Про етику державних } \\
\text { службовців» (2000) } \\
\end{array}$ \\
\hline Німеччина & Спеціальні адміністративні суди & $\begin{array}{l}\text { Конституція, Земельні закони про } \\
\text { державну службу }\end{array}$ \\
\hline США & $\begin{array}{l}\text { Консультативна комісія з питань етики і «конфлікту } \\
\text { інтересів», Комітет з питань етики, комітет з питань } \\
\text { стандартів офіційної поведінки, Комітет Сенату США } \\
\text { з етики, Адміністративне управління судів США, } \\
\text { Управління з етики в уряді }\end{array}$ & $\begin{array}{l}\text { Загальні принципи етичної поведінки } \\
\text { членів уряду і держслужбовців }\end{array}$ \\
\hline Польща & Найвища палата контролю & $\begin{array}{l}\text { Конституція Польської Республіки, } \\
\text { Закон про найвищу палату контролю }\end{array}$ \\
\hline
\end{tabular}

Джерело: сорормовано автором на основі [9-7].

го службовця, аналогу якому немає у світовій практиці. Документ містить дві частини: 1) вимоги до службової діяльності міністрів; 2) вимоги до решти службовців. Його своєрідність полягає в тому, що він, з одного боку, регламентує етику професійної діяльності службовців, починаючи від надання послуг населенню і завершуючи політичними консультаціями міністрам, а з другого визначає взаємні обов' язки службовців і міністрів" [6].

Аналіз багаторічного досвіду, накопиченого різними країнами, показує, що жоден етичний кодекс, навіть наділений властивостями правового акту небуде дієвим, якщо він не забезпечений відповідними механізмами контролю за його виконанням. Контроль становить невід'ємну функцію держави, а його реалізація вимагає створення спеціальних структур на всіх рівнях державної влади.

Одним із дієвих контрольних механізмів підтримки дотримання необхідного рівня етичності поведінки державних службовців у багатьох країнах стали спеціальні органи, які контролюють і оцінюють моральні вчинки: комісії та комітети з етики, адміністративні та корпоративні суди тощо. Їх повноваження можуть включати:

- розробку правил професійної етики та заходів впливу на їх порушників;

- розгляд звернень громадян з питань порушення правил професійної поведінки посадовими особами;

- підготовку рекомендацій та пропозицій щодо вдосконалення законодавства в сфрері службової етики;

- участь в обговоренні кандидатур на вакантні посади, в роботі атестаційних комісій;

- рекомендації керівництву щодо прийняття адміністративних та інших заходів до порушників етичних норм;

- доведення до відома громадян через засоби масової інформації фактів злісного порушення етичних норм і застосованих до них механізмів відповідальності [9].

У таблиці 1 представлені механізми контролю за дотриманням необхідного рівня етичності поведінки державних службовців різних країн.

У Франції основна увага приділяється створенню органів, які зобов'язані спостерігати, розкривати і відстежувати серйозні порушення в етиці поведінки державних службовців. Цими органами стали Центральний департамент по запобіганню корупції, Міжміністерська комісія з розслідування контрактів, що укладаються службовцями, і Вища рада з етики в національній політиці.

У Великобританії ще в 1855 році була створена відповідно до Королівського указу - Комісія по державній службі, яка працює до цих пір. Більш ніж п'ятдесят років тому з'явилася процедура етичного контролю і в парламенті Великобританії. Кожна його палата має свою посадову інструкцію - "Постійні правила", які визначають етичні аспекти діяльності парламентаріїв. Нині вироблено і діє більше 400 правил, що охоплюють всі сторони парламентської діяльності Великобританії [7].

У палаті громад парламенту Великобританії заснована посада парламентського Уповноваженого з питань стандартів поведінки. 31994 року діє спеціальний Комітет з питань стандартів в публічній сорері, до створення якого підштовхнули результати опитування громадської думки, який показав, що за десятирічний період оцінка громадськістю членів парламенту впала майже на $20 \%$. Повноваження Комітету досить широкі. Він може зобов' язати депутата вибачитися перед Палатою громад за порушення вимог етики або рекомендувати палаті громад на час усунути депутата від участі в роботі Палати (а так як у цей час його округ в парламенті не представлений, він не отримує платні і навіть не має права увійти до будівлі парламенту) [8].

Якщо розглянути ситуацію в Польщі, то тут головним органом контролю $€$ Найвища палата контролю (НПК) - головний орган державного контролю, який підпорядковується сейму Польської Республіки, діє на принципах колегіальності. Існувала вона вже у 19211939 рр. У повоєнний період (1949р.) відновила діяльність як незалежний від уряду орган, у 1952-1957 рр. була реорганізована в міністерство державного контролю [7].

В Японії реалізацію прийнятого у 2000 році Закону "Про етику державних службовців", а також затверджених урядовим указом Етичних правил державного службовця і норм адміністративних покарань за їх порушення, покликана забезпечувати створена для цього 


\begin{tabular}{|c|}
\hline Функції Управління службової етики в державних органах, США \\
\hline $\begin{array}{l}\text { розробка єдиної політики в області професійної етики для виконавчої } \\
\text { гілки влади і контроль над нею }\end{array}$ \\
\hline $\begin{array}{l}\text { контроль за реалізацією положень Закону про службову поведінку } \\
\text { державних службовців та забезпечення їх виконання }\end{array}$ \\
\hline моніторинг стану моральності на державній службі \\
\hline $\begin{array}{l}\text { підготовка змін до законодавчих актів з етики та конфлікту інтересів на } \\
\text { державній службі на підставі результатів моніторингу }\end{array}$ \\
\hline розробка єдиних освітніх програм і тренінгів \\
\hline $\begin{array}{l}\text { координація діяльності комісій з етики штатів щодо забезпечення } \\
\text { дотримання вимог Закону про службову поведінку службовців державних } \\
\text { органів }\end{array}$ \\
\hline $\begin{array}{l}\text { проведення щорічних конференцій для посадових осіб державних органів і } \\
\text { організацій, що забезпечують виконання Закону та етичної програми }\end{array}$ \\
\hline $\begin{array}{l}\text { координація діяльності всіх ланок системи управління моральними } \\
\text { відносинами }\end{array}$ \\
\hline $\begin{array}{l}\text { контроль за виконанням вимог до службового поводження державних } \\
\text { службовців, що містяться в Законі, і формування особистої моральної } \\
\text { культури кожного державного службовця }\end{array}$ \\
\hline
\end{tabular}

Рис. 2. Функції Управління службової етики в державних органах, США

Джерело: складено автором на основі [8].

Комісія з етики державних службовців, що має складну систему призначення її керівництва для забезпечення незалежності та стабільності діяльності [9].

У США ще при президенті Дж. Кеннеді була заснована Консультативна комісія з питань етики і "конфлікту інтересів". У середині 60-х років минулого століття в кожній з палат конгресу були створені постійні комітети з етики: в 1964 р в сенаті - комітет з питань етики, в 1967 р в палаті представників - комітет з питань стандартів офріційної поведінки. Контроль за дотриманням етичних норм щодо членів і співробітників апарату Палати представників Конгресу покладено на Комітет з питань стандартів офріційної поведінки Палати представників Конгресу США; щодо сенаторів і співробітників Сенату - на Комітет Сенату США з етики; щодо федеральних суддів і співробітників апаратів судів - на Адміністративне управління судів США. Координацію роботи всіх цих комітетів здійснює Управління з етики в уряді.

У Німеччині функція контролю над чиновництвом забезпечується системою спеціальних адміністративних судів, де громадяни можуть оскаржити порушення їх прав і законних інтересів органами публічної влади. Такі суди діють на трьох рівнях: першої інстанції, земельному і федеральному. Їх завдання - захист громадян від свавілля чиновників. Щорічно вони розглядають десятки тисяч справ. Досвід адміністративного судочинства для нас на сьогодні $є$ особливо цікавим та актуальним [9].

Система контролю за дотриманням етичних норм забезпечується і активною участю в цьому процесі і самих державних службовців.

Комітет міністрів Ради Європи, розробляючи Рекомендації у вигляді Модельного кодексу для країн-учасниць РЄ, включив в них такий контрольний механізм, як зобов'язання державного службовця: "державний служ- бовець повинен, відповідно до закону, повідомити відповідні органи якщо йому чи їй стає відомо про порушення цього Кодексу іншими державними службовцями", а також "повідомляти компетентним органам щодо будь-якого доказу, повідомлення, підозри про неправомірну чи злочинну поведінку щодо державної служби, що стали йому чи їй відомі під час чи у зв' язку з його чи її працевлаштуванням. Розслідування повідомлених фрактів повинно здійснюватися компетентними органами ". Цей принцип розглядається як відображення громадянського обов'язку працівника [5]. У США відповідно до Закону про реформу етичних норм (1989 г.) дотримання цього принципу є обов'язковим для кожної посадової особи державних органів усіх гілок влади.

Варто зазначити, що не менш цікавою для нас $€$ і система управління процесом етизаціі державної служби. Уже в кінці минулого століття стало очевидно, що чітко скоординовані удари по "недобросовісних" чиновниках і не уніфріковані заходи щодо забезпечення етичності кадрового корпусу державної служби, не дають очікуваних результатів. Це підштовхнуло владу до створення системи управління моральними відносинами в державній службі.

У США формування системи органів з управління етичним аспектом почалося з "освіти", відразу після прийняття Закону 1978 року Управління службової етики в державних органах (Office of Government Ethics OGE). Сьогодні цей орган, поряд з Корпорацією державної і муніципальної служби (США) (Corporation for National and Community Service (CNCS), входить, до числа 69 затверджених Конгресом США незалежних агентств, в структуру виконавчої гілки влади США. Основними характеристиками правового статусу OGE як незалежного агентства $€$ позавідомче положення, незалежний від федеральних міністерств характер діяльності, право законотворчої ініціативи в сфері своїх повноважень, колегіальна форма управління власною сорерою діяльності, а також наявність обов'язкового представництва в його складі представників правлячих партій [9].

Управління очолює директор, який призначається президентом США на п'ятирічний термін. Місія Управління полягає в здійсненні контролю на рівні виконавчої гілки влади щодо запобігання і вирішення конфлікту інтересів в середовищі урядовців. Управління виховує у службовців високі етичні стандарти і зміцнює віру громадськості в те, що діяльність уряду здійснюється неупереджено і чесно.

Місія Управління визначає і його основні завдання - "всеосяжне регулювання з метою запобігання конфрлікту інтересів посадових осіб всіх виконавчих органів влади" і видання розпоряджень, що встановлюють "детальний і чіткий набір стандартів поведінки для службовців органів виконавчої влади". Функції Управління представлені схематично на рисунку 2. 
Це передбачає створення програм навчання управлінських кадрів, спрямованих на поглиблене вивчення нюансів професії та букви Закону, а також контроль якості засвоєння отриманих знань і вмінням реалізувати їх на практиці.

Як зазначає Лагодієнко О. [3], "із найсвіжіших документів достатньо якісним виглядає приклад оновлених документів Австралії. По-перше, вони зроблені в сучасному "антибюрократичному" стилі. По-друге, орієнтовані не лише на етичну сторону, а в цілому на те, якою повинна бути державна служба. По-третє, кодекс супроводжують численні додатки для самооцінки, порадник щодо прийняття рішень працівниками, порадник для організації супровідних процесів для підрозділів по персоналу, сайти, тренінги, постери та відео. А головне, по-четверте, ці зміни запроваджено найвищими посадовцями з серйозністю національної програми".

\section{ВИСНОВКИ 3 ПРОВЕАЕНОГО АОС ІАЖЕННЯ І ПЕРСПЕКТИВИ ПОАА ЬШИХ АОС ІАЖЕНЬ}

Одним з найважливіших факторів в професійному становленні державного службовця, як показує міжнародний досвід, $є$ вивчення етичних принципів роботи та моральне виховання.

У практиці багатьох країн широко розповсюджений досвід впровадження предмета етики, а також етикету ділових відносин у програми підготовки, перепідготовки та підвищення кваліфікації державних службовців різного рангу.

\section{Література:}

1. United Communist Party of Turkey and Others v. Turkey. - Режим доступу: https://www.tandfonline.com/doi/abs/10.1080/13642989808406732

2. Карковська Р.І. Етична організаційна поведінка у вітчизняних психологічних дослідженнях [Електронний ресурс] / Р.І. Карковська. - 2017. - Режим доступу: http://orgpsy-journal.in.ua/userfiles/issues/i9/n9/ 8.pdf

3. Лагодієнко О. Правила бюрократів. Службовцям прищеплять корпоративні цінності [Електронний ресурс] / О. Лагодієнко, І. Хілобок / / Новое Время. - 2016. Режим доступу: https://nv.ua/ukr/publications / pravila-bjurokrativ-sluzhbovtsjam-prishchepljat-korporativni-tsinnosti-108900.html?new_site $=1$

4. Огренчук А. Европейские стандарты госслужбы [Електронний ресурс] / А. Огренчук / / Юридическая практика. - 2011. - Режим доступу: http://pravo.ua/ article.php?id $=10010190$

5. Рекомендація No R (2000) 10 Комітету Міністрів державам - членам Ради Європи щодо кодексів поведінки державних службовців (прийнята Комітетом міністрів на 106 сесії 11 травня 2000 року) [Електронний ресурс]. - 2000. - Режим доступу: http:// www.dridu.dp.ua/cpk/Lib/7_Zapobigannya\%20 ta \% 20protydiya \% 20proyavam \% 20korup/Legislation/Legislature/Rekomend_poved_DS.pdf

6. Рудакевич M.I. Формування етики державних службовців в умовах демократизації і професіоналізації державного управління: автореферат дисертації на здо- буття наукового ступеня доктора наук з державного управління. - К., 2007.

7. Світові моделі державного управління: досвід для України / За заг. ред. Ю.В. Ковбасюка, С.В. Загороднюка, П.І. Крайніка, Х.М. Дейнеги.- К.: НАДУ, 2012. $-612 c$.

8. Шувалова Н.Н. Управление нравственными отношениями в системе государственной службы: ориентация на успех / Н.Н. Шувалова / / Право и управление. XXI век. - 2013. - С. 41-48.

9. Этика государственной и муниципальной службы: учебник и практикум [Електронний ресурс] // ЮРАЙТ. Режим доступу: https://stud.com.ua/161286/menedzhment/etika_derzhavnoyi_i_munitsipalnoyi_sluzhbi

References:

1. Selected judgments of the European court of human rights (2007), "United Communist Party of Turkey and Others v. Turkey", [Online], available at: https:// www.tandfonline.com/doi/abs/10.1080/13642989808406732 (Accessed 10 Feb 2019).

2. Karkovska, R.I. (2017), "Ethical organizational behavior in domestic psychological research", Orhanizatsiina psyholohiia. Ekonomichna psyholohiia, vol. 2$3(9-10)$, pp. $57-70$.

3. Lagodienko, O. and Hlibok, I. (2016), "The rules of the bureaucrats. Employees are grafted into corporate values", Novoye Vremya, [Online], available at: https:// nv.ua/ukr/publications/pravila-bjurokrativ-sluzhbovtsjam-prishchepljat-korporativni-tsinnosti-108900.html?new_site=1 (Accessed 10 Feb 2019).

4. Ogrenchuk, A. (2011), "European Standards of the State Service", luridicheskaia praktika, [online], available at: http://pravo.ua/article.php?id=10010190 (Accessed 10 Feb 2019).

5. Committee of Ministers of the Council of Europe (2000), "Recommendation vol. R (2000), 10 of the Committee of Ministers to member States of the Council of Europe on codes of conduct for civil servants", [Online], available at: http://www.dridu.dp.ua/cpk/Lib/ 7_Zapobigannya \%20ta\%20protydiya\%20proyavam \%20 korup/Legislation / Legislature/Rekomend_poved_DS.pdf (Accessed 10 Feb 2019).

6. Rudakevich, M.I. (2007), "Formation of Ethics of Public Servants in the Conditions of Democratization and Professionalization of Public Administration", Ph.D. Thesis, Public Administration, National Academy of Public Administration, Kyiv, Ukraine.

7. Kovbasiuk, lu.V. Zahorodniuk, S.V. Krainik, P.I. and Dainehy, H.M. (2012), Svitovi modeli derzhavnoho upravlinnia: dosvid dlia Ukrainy [World models of public administration: experience for Ukraine], NADU, Kyiv, Ukraine.

8. Shuvalova, N.N. (2013), "Management of moral relations in the system of civil service: orientation to success", Right and management. XXI Century, vol. 2 (27), pp. $41-48$.

9. Shuvalova, N.N. (2018), "The Ethics of the State and Municipal Service", [Oline], available at: https:// stud.com.ua/161286/menedzhment/etika_derzhavnoyi_i_munitsipalnoyi_sluzhbi (Accessed 10 Feb 2019). Стаття надійшла до редакиіï 13.02.2019p. 